\title{
AN ASSESSMENT OF DAIRY FARM STRUCTURE AND CHARACTERISTICS OF DAIRY PRODUCTION SYSTEMS IN SERBIA
}

\author{
V. Bogdanović ${ }^{1}$, R. Đedović ${ }^{1}$, P. Perišić ${ }^{1}$, D. Stanojević ${ }^{1}$, M.D. Petrović ${ }^{2}$, \\ S. Trivunović ${ }^{3}$, D. Kučević ${ }^{3}$, M.M. Petrović ${ }^{4}$ \\ ${ }^{1}$ Institute of Animal Sciences, Faculty of Agriculture, Univeristy of Belgrade, Nemanjina 6, 11080 \\ Zemun-Belgrade, Serbia \\ ${ }^{2}$ Agronomic Faculty Čačak, University of Kragujevac, Serbia \\ ${ }^{3}$ Department of Animal Science, Faculty of Agriculture, University of Novi Sad, Serbia \\ ${ }^{4}$ Institute for Animal Husbandry, Belgrade, Serbia \\ Corresponding author: vlbogd@agrif.bg.ac.rs \\ Original scientific paper
}

Abstract: In order to have a more precise description of dairy farm structure and characteristics of dairy production systems, as well as to assess possibilities for improving production and farming conditions in which milk production is organized, a survey based research was directed at a select group of farms across the Serbia. 1180 questionnaires have been mailed to farmers whose farms are registered for either cattle or mixed production. Questionnaire was divided into 6 sections: general information of the farm, agricultural and structural information, zootechnical information, sanitary and veterinarian information, information about education and extension, and information on the perspectives of future farming. About $59 \%$ of analysed farms have size up to 20 ha, with average size of about 10 ha. On the other hand, about $55 \%$ farms raises up to 15 cows and heifers with average of 6 heads per farm, while 3\% of farms have more than 200 cows and heifers. Over $86 \%$ of surveyed farmers intend to expand existing farm production, mainly by increasing the number of animals, stricter selection and improvement of the conditions for feeding, housing, care and milking. About $75 \%$ of farmers have expressed a positive expectation from future membership of Serbia in EU, although these expectations are not clearly defined.

Key words: Dairy cattle, dairy farm, dairy production system, survey

\section{Introduction}

Dairy cattle production has traditionally been one of the most important branches of livestock production in Serbia. Since the first official Simmental cattle imports in the second half of the nineteenth century until today it has passed 
through various stages of development. However, despite several decades of development, the current state of dairy cattle production in Serbia is not completely satisfactory. Generally speaking, the production of milk is done with a significantly reduced number of cattle. A negative trend has been visible, for more than two decades, in the numbers of cattle and all forecasts indicate that this tendency will also continue in the future. The situation is additionally aggravated by the existence of a large number of non-commercial, mostly elderly households, with poor equipment and motivation, with which it is not possible to organize an efficient production, or make any long-term production plans (Perišić et al., 2011; Perišić et al., 2006).

Serbia's farm structure is very complex, consisting of small subsistence agricultural households, small semi-subsistence farms, large family farms, as well as privatized large enterprises with a mixed ownership structure (Bogdanov and Božić, 2010). The average size of an agricultural farm in Serbia is between 3 and 4 ha, on average $3.2 \mathrm{ha}$. According to the 2002 Census, which included a Census of agriculture as well, some $46 \%$ of farms had up to 2 ha, while only $6 \%$ of the farms had over 10 ha (Statistical Office of the Republic of Serbia, 2003). However, households which are primarily registered for dairy cattle production and deal with commercial activities have a somewhat larger size. Bearing that in mind, the aim of this paper has been to assess dairy farm structure and characteristics of dairy production systems, as well as to assess possibility of improving dairy production systems in Serbia.

\section{Material and Methods}

In order to have a more precise description of dairy farm structure and characteristics of dairy production systems, as well as to assess possibilities for improving production and farming conditions in which milk production is organized, a survey based research was directed at a select group of farms across the Serbia. Most of the farms involved in this research represent commercial farms involved in the program of continuous agricultural extension service and regarding farm and production parameters they are above the average agricultural farm. Moreover, these farms will most likely represent the backbone of future dairy production development in Serbia.

A total of 1180 surveys, i.e. the questionnaires, were sent to farmers whose farms are either registered for cattle production or mixed production, i.e. farmers who, besides cattle production, deal with sheep or goat production or certain plant production (crop, vegetables, fruit, etc.). The questionnaires that were sent to the farmers comprised of several parts and involved (1) General information of the farm, (2) Agricultural and structural information, (3) Zootechnical information, (4) Sanitary and veterinarian information, (5) Information about education and extension, and (6) Information on the perspectives of future farming. Each one of 
the above mentioned parts consisted of several questions which described in more details certain aspects of dairy cattle production and farm management. The sample, which was based on random selection of farms within the statistical region (Statistical Office of the Republic of Serbia, 2011), covered the entire territory of the Republic of Serbia, except for the region of Kosovo and Metohija.

Of the total number of 1180 distributed surveys, a total number of 209 responses, or $17.7 \%$, were received. After filtering and excluding questionnaires that were not properly filled in, a total number of 153 questionnaires was used for final analysis. For the analysis of the received surveys, the analysis of frequency distribution and descriptive data analysis have been used within the statistical package "GenStat 14.2" (VSN International Ltd., 2011).

\section{Results and Discussion}

Production of cow's milk in Serbia is mainly organized in semi-intensive and intensive production systems, while extensive systems are much less frequent and mostly related to undeveloped or remote mountainous areas. Common to all the farmers who are engaged in dairy cattle farming, compared to the average farmer with mixed farming, is a larger farm size, bigger number of animals that are grown on the farm, higher level of technological knowledge and greater openness to technological improvements of production.

Structure of dairy farms. Findings from this research shown that Simmental cattle are kept on $73 \%$ of analysed farms, while HF and Black and White cattle are kept on about $13 \%$ of all farms. On about $7 \%$ farms both breeds are kept, while less than $3 \%$ of farms kept local, autochthonous breeds, various crossbreds or pure beef breed (Hereford). About 4\% of analysed surveys did not have answer on this question.

In the context of dairy cattle production it is a characteristic that the Simmental breed is mainly kept on small- and medium-size farms, while HF and Black and White cattle are kept on medium- and large-size farm. This is particularly the case in the Serbia - North (NUTS1), i.e. Vojvodina and Belgrade, where the majority of the larger commercial herds with HF and Black and White cattle can be found. On the other hand, in the Serbia - South (NUTS1), i.e. south of Belgrade, Simmental cattle are dominant either on medium- or large-size commercial units.

Based on the analysis from obtained answers, the milk production in Serbia is organized on farms with size in the range between 1.3 ha and up to 4000 ha. Distribution of dairy cattle farms according to farm size is shown in table 1. 
Table 1. Distribution of dairy farms according to farm size (owned + rented land in ha)

\begin{tabular}{|c|c|c|}
\hline Size of farms & Share of total number of farms & Average size of farm in group \\
\hline$<20$ ha & $59.00 \%$ & $10.15 \mathrm{ha}$ \\
\hline $20-50 \mathrm{ha}$ & $20.00 \%$ & $29.82 \mathrm{ha}$ \\
\hline $50-100 \mathrm{ha}$ & $6.50 \%$ & $66.43 \mathrm{ha}$ \\
\hline $100-200 \mathrm{ha}$ & $2.50 \%$ & $131.00 \mathrm{ha}$ \\
\hline$>200 \mathrm{ha}$ & $6.00 \%$ & $1246.00 \mathrm{ha}$ \\
\hline Non-answered question & $6.00 \%$ & --- \\
\hline
\end{tabular}

However, if all the farms larger than 100 ha are excluded from the analysed sample, the average size of $85 \%$ of the farms with an area up to 100 ha is 18.3 ha.

The average number of cows also varies from one farm to another. Distribution of farms according to number of cows and heifers is shown in table 2 .

Table 2. Distribution of dairy farms according to number of cows and heifers raised on farm

\begin{tabular}{|c|c|c|}
\hline $\begin{array}{c}\text { Number of cows \& heifers } \\
\text { raised on farm }\end{array}$ & Share of total number of farms & $\begin{array}{c}\text { Average number of cows and } \\
\text { heifers in group }\end{array}$ \\
\hline$<15$ & $55.00 \%$ & 6.3 \\
\hline $15-30$ & $15.00 \%$ & 22.1 \\
\hline $30-100$ & $5.00 \%$ & 55.3 \\
\hline $100-200$ & $5.00 \%$ & 144.0 \\
\hline$>200$ & $3.00 \%$ & 390.0 \\
\hline Non-answered question & $17.00 \%$ & --- \\
\hline
\end{tabular}

If we exclude from the analysis all the farms with more than 100 cows, which is about $8 \%$ of farms, the average number of cows for $75 \%$ of the farms is about 13 heads, or some 1.4 heads per hectare.

Characteristics of dairy production systems. The usual way of keeping dairy cows is in free stalls, while tied-up systems are more and more seldom. Stables with the free system are open or semi-open with appropriate outlets, while keeping the cows in pasture is seldom practiced.

In terms of reproductive characteristics, no significant statistical differences were observed between the cattle breeds on the farms that were included in this analysis. The first insemination of heifers is performed at the age of 15-16 months, while the first calving is at the age of 24-25 months and these results are consistent with previously determined values for these two breeds in Serbia (Novaković et al., 2011, Petrović et al., 2008). The last calving is at the age of about 8 years with HF and about 9 years with Simmental cattle. Weaning of calves after birth is on average at the age of 2.5 months, whereas the HF calves are separated from dams immediately after calving or immediately after the colostrum period, while the Simmental calves are left with dams several weeks longer. The results obtained by analyzing the responses from surveyed farmers indicate that a 
similar reproductive management is applied on all cattle farms specialized in dairy production regardless of the fact which breed of the cattle is kept on the farm.

All the farmers dealing with specialized dairy production are well aware of the importance of proper selection and breeding methods. More than $80 \%$ of cows in Serbia are inseminated, while about $20 \%$ are natural mated and it is mainly done in remote, mountainous areas where there is no infrastructure necessary for insemination. Farmers who keep Simmental breed, in addition to domestic bulls, use imported bulls for insemination, mainly from Germany and Austria, while farmers who keep HF use bulls from USA, Canada, Germany and the Netherlands. The main criteria in selecting bulls are their exterior characteristics, production traits of their daughters or recommendations of the Centre for AI.

All the farmers involved in this analysis adapt animal feeding to the physiological status of the animal, paying particular attention to milk yield of the animals or their reproductive status. About $92 \%$ of farmers prepare their own livestock feed, while $55 \%$ of farmers buy ready-made concentrates from animal feed manufacturers. Farmers that prepare their own feed, mainly produce the entire amount of forage and one part of concentrated feed. In terms of forage, farmers prepare hay from clover or alfalfa, corn silage and, increasingly, haylage. When it comes to concentrated feed, farmers usually produce food grain, such as corn, soybean or sunflower, while they only acquire on the market additives or necessary premixes. About $78 \%$ of surveyed farmers buy vitamin and mineral supplements necessary in cattle's diet.

High milk production, time-limited milking and healthy udders of cows are priority objectives of cattle farms. One of the key technological processes in milk production is milking and three milking systems are predominant in Serbia: milking in herringbone milking parlours, milking with the assistance of stable milk line and vacuum line and milking using milking machines in special bins. Larger farms specialized for milk production tend to have milking parlours, while the system of milk line or milking by using milking machines is applied on small farms. Almost all surveyed farmers are familiar with the importance of maintaining proper hygiene of the udder and the milking process itself, so the number of somatic cells per ml of milk is on average 310.000 , with variations from 100.000 to 400.000 , which is below the maximum allowed by national legislation which is 400.000 somatic cells per ml of milk (Annonymous, 2009).

Over $86 \%$ of surveyed farmers intend to expand existing farm production, mainly by increasing the number of animals, stricter selection and improvement of the conditions for feeding, housing, care and milking. About $6.5 \%$ of farmers do not plan to expand their production for the time being. Of no less importance is the fact that about $75 \%$ of surveyed farmers expect certain benefits from future EU membership, even though they are aware that they should, also, expect a lot more adaptation. On the other hand, about $19 \%$ of farmers do not expect any benefit from Serbia's potential EU membership. 
In addition to specific infrastructure improvements related to new stables or farm facilities, farm machinery and similar, there are two predominant ways, among surveyed farmers, of improving production. These are the increase of the herd size and more intensified head selection based on milk traits. Such determination of farmers coincides with the results of previous researches in this area. Thus Kučević et al. (2011) found that in breeding stock that are under the milk recording, it is the size of the farm that is one of the most important sources of variability in milk traits. Farms that were classified as large or had more than 50 cows had an average milk yield that was higher than small or medium-sized farms, regardless of whether they were situated in Vojvodina or central Serbia. Increasing the size of the herd contributes to the intensification of production, and thereby easier acceptance of new technological solutions, especially if they contribute to measurable improvement of production.

\title{
Conclusion
}

For the success of any dairy farm optimization program or improvement of dairy cattle production parameters, it is necessary that the farmers are interested in such a thing, and are ready to apply some new solutions on their own farms. Although the results from this study cannot be generalized to all farms that regularly or occasionally deliver milk to the dairies, of which according to estimates there are about 149.000 in Serbia, they indicate that there are potentials for improvement in terms of production, both from the aspect of farmers and from the aspect of optimal utilization of available farm resources. Analysed answers from surveys indicate that for future development of dairy farms as well as dairy production systems in Serbia very important issues are the age of owner, regular contact with Agricultural Extension Services, willingness for applying new technological solutions, Ministry support, and availability of bank credits or other financial sources.

\section{Acknowledgment}

This study was supported by the Ministry of Education, Science and Technological Development, Republic of Serbia, projects No. TR31086, project No. TR 31053, project No. III46006 and project No. III46009.

\section{Procena strukture mlečnih farmi i karakteristika sistema za proizvodnju mleka u Srbiji}

\author{
V. Bogdanović, R. Đedović, P. Perišić, D. Stanojević, M.D. Petrović, S. Trivunović, \\ D. Kučević, M. M. Petrović
}




\section{Rezime}

U cilju preciznijeg opisa strukture mlečnih farmi i karakteristika sistema za proizvodnju mleka, kao i procene mogućnosti za unapređenje proizvodnje i farmskih uslova u kojima se proizvodnja mleka organizuje, sprovedena je anketa među poljoprivrednim proizvođačima (farmerima) širom Srbije. Ukupno je poslato 1180 anketa farmerima čije su farme registrovane za govedarsku ili mešovitu proizvodnju. Upitnik koji je poslat farmerima sastojao se iz 6 delova i obuhvatao je opšte informacije o farmi, poljoprivredne i strukturne informacije, zootehničke informacije, sanitarne $i$ veterinarske aspekte proizvodnje, edukaciju i savetodavstvo, kao i perspektive budućeg poslovanja. Oko 59\% analiziranih farmi ima veličinu do $20 \mathrm{ha}$, sa prosekom od oko $10 \mathrm{ha}$. Sa druge strane, na oko 55\% farmi odgaja se do 15 krava i junica, sa prosekom od 6 grla po farmi. Preko $86 \%$ anketiranih farmera namerava da proširi postojeću proizvodnju i to uglavnom povećanjem broja životinja, strožijom selekcijom roditeljskih parova, kao i unapređenjem uslova ishrane, smeštaja i nege. Oko $75 \%$ anketiranih farmera izrazilo je pozitivna očekivanja od budućeg članstva Srbije u EU, iako ta očekivanja nisu uvek jasna ili precizno definisana.

\section{References}

ANNONYMOUS (2009). Rulebook on quality of raw milk. Official Gazette of RS, No. 21/2009.

BOGDANOV N., BOŽIĆ D. (2010). Review of agriculture and agricultural policy in Serbia. In: Agriculture in the Western Balkan Countries. Ed. Tina Volk, Leibniz Institute of Agricultural Development in Central and Eastern Europe. Studies on the Agricultural and Food Sector in Central and Eastern Europe, Vol. 57, 189-218. GENSTAT FOR WINDOWS 14th EDITION (2011). VSN International Ltd., UK. KUČEVIĆ, D., TRIVUNOVIĆ, S., RADINOVIĆ, M., PLAVŠIĆ, M., SKALICKI, Z., PERIŠIĆ, P. (2011). The effect of the farm size on milk traits of cows. Biotechnology in Animal Husbandry, 27 (3), 951-958.

NOVAKOVIĆ Ž., SRETENOVIĆ LJ., ALEKSIĆ S., PETROVIĆ M.M., PANTELIĆ V., OSTOJIĆ-ANDRIĆ D. (2011). Age at first conception of high yielding cows. Biotechnology in Animal Husbandry, 27 (3), 1043-1050.

PERIŠIĆ P., SKALICKI Z., BOGDANOVIĆ V., PETROVIĆ M.M. (2006). Simentalska rasa i pravci njenog razvoja. Biotechnology in Animal Husbandry, 22 (Special Issue): 231-244.

PERIŠIĆ P. SKALICKI Z. BOGDANOVIĆ V. (2011). The state in the sector of milk production in European Union and in our country. Biotechnology in Animal Husbandry, 27 (3): 315-327. 
PETROVIĆ M.D., BOGDANOVIĆ V., BOGOSAVLJEVIĆ-BOŠKOVIĆ S., ĐOKOVIĆ R. (2008). Uticaj uzrasta pri prvoj oplodnji na reproduktivne, proizvodne i funkcionalne osobine krava simentalske rase. Contemporary Agriculture, 57 (3-4), 150-157.

STATISTICAL OFFICE OF THE REPUBLIC OF SERBIA (2011). Opštine i regioni u Republici Srbiji. Odgovara Dragan Vukmirović, Republički zavod za statistiku, Beograd.

STATISTICAL OFFICE OF THE REPUBLIC OF SERBIA (2003). Agriculture: The Census of the population, households and dwellings in 2002. Statistical Office of the Republic of Serbia, Belgrade. 